\title{
COMPARISON OF TREATMENT PERFORMANCE BETWEEN CONSTRUCTED WETLANDS WITH DIFFERENT PLANTS
}

\author{
G.Baskar $^{1}$, V.T.Deeptha ${ }^{2}$, R.Annadurai ${ }^{3}$ \\ ${ }^{I}$ Professor, Department of Civil Engineering, SRM University, Kattankulathur (TN), India \\ ${ }^{2}$ Assistant Professor, Department of Civil Engineering, SRM University, Kattankulathur (TN), India \\ ${ }^{3}$ Head of Department, Department of Civil Engineering, SRM University, Kattankulathur (TN), India
}

\begin{abstract}
Constructed wetlands have gained much importance for treating domestic, industrial and agricultural wastes and are considered as an effective secondary or tertiary treatment method. The main characteristics affect the removal efficiency of constructed wetland are the vegetation type, hydraulic residence time and substrate. The aim of the present study is to examine effect of vegetation type on organic and nutrient removal under varying hydraulic residence time in constructed wetlands. With this in mind, we have designed, constructed and operated two pilot-scale horizontal subsurface flow constructed wetlands having two different wetland vegetation plants in our open-air laboratory receiving pre-treated domestic wastewater by varying hydraulic residence time as 2, 4, 6 and 8 days. The influent wastewater is rich in orgnic matter with high variability presence of nutrients. In the first unit, the removal efficiency of COD, BOD, TN, and TP was increased from 39 to 69\%, 29 to 56\%, 23 to 45\% and 25 to $75 \%$ when there was an increase in HRT from 2 days to 8 days respectively. In the second unit, the removal efficiency of COD, BOD, TN, and TP was increased from 31 to 68\%, 25 to 52\%, 26 to $36 \%$ and 40 to 77\% when there was an increase in HRT from 2 days to 8 days respectively. It was found that vegetation type influenced concentration reduction. A 6-day hydraulic residence time is suggested for an acceptable level of treatment in these systems.
\end{abstract}

Keywords: constructed wetlands, organic, nutrient, Phragmites australis, Typha latifolia, hydraulic residence time.

\section{INTRODUCTION}

Wetlands are areas that are wet during part or all of the year. Natural wetlands have long been recognized as capable of reducing the pollution load of the adjacent water bodies. Wetlands may be artificially constructed either to reintroduce a wetland in an area or to treat wastewater, in which case they are also referred to as treatment wetlands. Constructed wetlands are manmade systems that mimic the functions of natural wetlands.

The wetland is constructed in shallow pits installed with a drain pipe in a bed of pebbles or gravels and sand layers planted with native vegetation. An impermeable membrane is provided at the bottom to prevent percolation of wastewater into the soil or aquifer below. The vegetation may be emergent macrophyte, floating plant or submerged plant species.

The basic types of treatment wetlands are free water surface (FWS) wetland and subsurface flow (SSF) wetland. The SSF constructed wetland is further classified into horizontal subsurface flow (HSSF) and vertical subsurface flow (VSSF).

As the wastewater flows through the constructed wetland, it is treated by the various processes of sedimentation, filtration, oxidation, reduction, adsorption, precipitation, bacterial metabolism, nitrification, denitrification, and plant uptake [1]. Constructed wetlands have the potential to treat a variety of wastewaters by removing organics, suspended solids, pathogens, nutrients and heavy metals [2].

The use of constructed wetlands has proved to be a reliable solution in developed countries. It is finding wider acceptability among developing countries, as it appears to offer a more economical and ecologically acceptable solution to water pollution management problems. It is especially useful for small communities that cannot afford the conventional high-cost treatment methods.

The main characteristics affect the removal efficiency of constructed wetland are the vegetation type, hydraulic residence time and substrate. The aim of the present study is to examine effect of vegetation type on organic and nutrient removal under varying hydraulic residence time in constructed wetlands. With this in mind, we have designed, constructed and operated two pilot-scale horizontal subsurface flow constructed wetlands.

The constructed wetland is a natural biological treatment process that is normally used to treat variety of wastewater such as sewage $[3,4,5,6]$, polluted river $[7,8]$, farmyard 
runoff [9], landfill leachate [10], swine effluent [11], dairy parlor wastewater [12] and residual dyebath [13].

\section{MATERIALS AND METHODS}

\subsection{Constructed Wetland Pilot Units}

The study site is located in the SRM University (latitude $12^{\circ} 42^{\prime} \mathrm{N}$, longitudinal $80^{\circ} 02^{\prime}$ E) campus, Kattankulathur, Southern part of India. The climate of the area is tropical with an average annual rainfall of $1330 \mathrm{~mm}$.

These two pilot units were designed and built in out oper-air laboratory. These units were filled with a substrate of bottom layer $(0.15 \mathrm{~m}$ depth) gravel $(6 \mathrm{~mm}$ size $)$ over sand layer $(0.09$ $\mathrm{m}$ depth of 0.3 to $0.5 \mathrm{~mm}$ size). First unit was established with an emergent plant species Phragmites australis which is coed as PAGS (Fig. 1). The second unit was established with an emergent plant species Typha latifolia which is coded as TLGS (Fig. 2). The units were established in our open-air laboratory receiving pre-treated domestic wastewater by varying hydraulic residence time as 2, 4, 6 and 8 days.

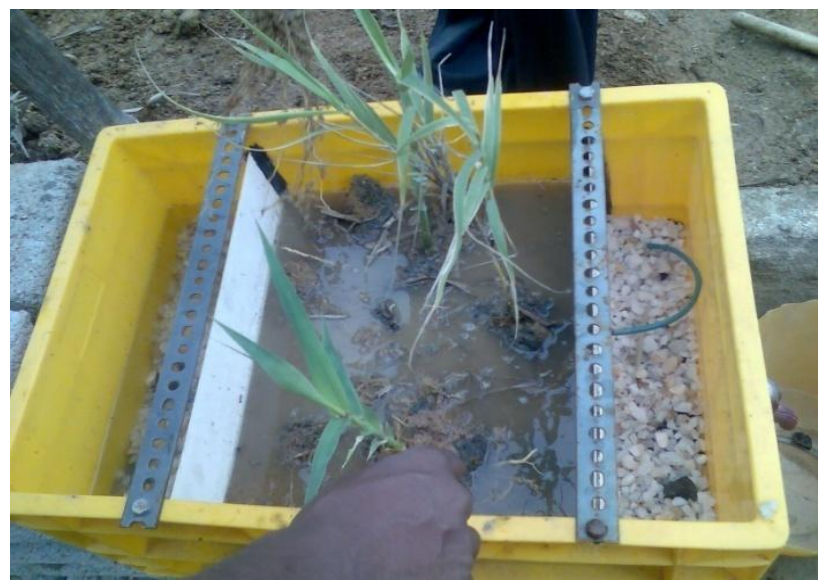

Fig -1: Constructed wetland pilot unit PAGS

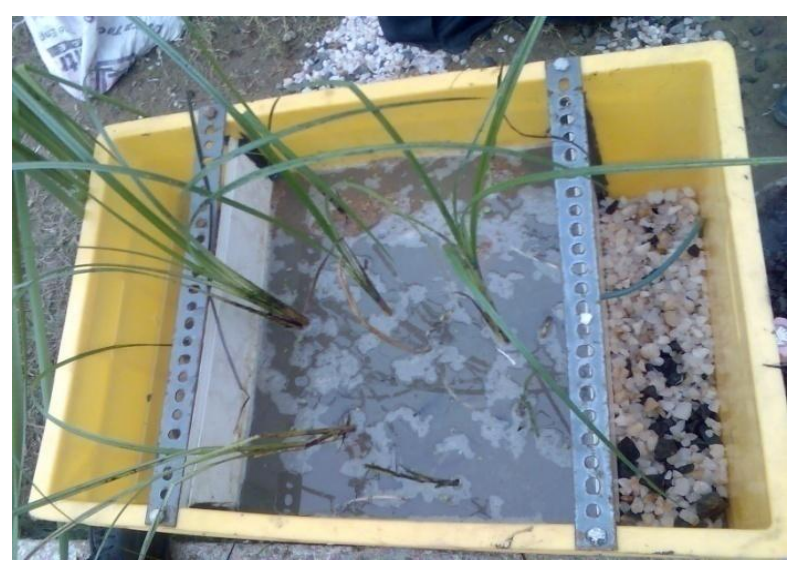

Fig -2: Constructed wetland pilot unit TLGS
These two pilot units were operated in batch mode receiving pretreated campus domestic wastewater. The inlet chamber $(0.41 \times 0.12 \times 0.27) \mathrm{m}$ size and outlet chamber $(0.12 \times 0.41 \times 0.27)$ $\mathrm{m}$ size were formed by providing fiber sheets as partitions. In the inlet chamber, an opening was provided at the bottom to allow wastewater into the treatment zone. To collect treated wastewater, an opening or a valve guarded by net filter was provided.

\section{RESULTS AND DISCUSSION}

\subsection{Influent Wastewater Characterization}

The campus pre-treated domestic wastewater from the existing sewage treatment plant to the small-scale units was characterized over a six month period (Table 3).

Table -3: Properties of Influent Wastewater

\begin{tabular}{|l|l|l|l|l|}
\hline \multirow{2}{*}{$\begin{array}{l}\text { Sl. } \\
\text { No. }\end{array}$} & Parameter & \multicolumn{3}{|l|}{ Concentrations in mg/l } \\
\cline { 3 - 5 } & & Min & Max & Mean \\
\hline 1. & BOD & 101 & 3390 & 643.2308 \\
\hline 2. & COD & 315 & 1823 & 674.923 \\
\hline 3. & TN & 2.28 & 196 & 60.37231 \\
\hline 4. & TP & 0.06 & 32.6 & 14.01385 \\
\hline
\end{tabular}

The parameters Biological Oxygen Demand (BOD), Chemical Oxygen Demand (COD), Total Nitrogen (TN) and Total Phosphorus (TP) were determined based on standard methods [14]. The analysis were done immediately after sample collection, otherwise were properly stored. Wastewater from an university campus differs both in quantity and quality unlike municipal domestic wastewater.

There was reduction in quantity during weekends, examination periods, holidays, and vacation. There was variation in quality because of mix up of wastewater from academic blocks, hostels, canteen, chemistry labs, biotechnology labs, etc.

It was found that there was high concentration of BOD, TN in the samples during the weekdays when the students strength if high. COD is also high probably because of wastewater from the chemistry labs. Normally, municipal wastewater has lesser COD but in the college campus it becomes an important parameter to be treated. Low values of BOD, COD occur during heavy rainfall which indicates clear dilution effect. The concentration of $\mathrm{BOD}, \mathrm{TN}$ tends to decrease during vacation and increase once university had reopened.

\subsection{Organics and Nutrient Removal in PAGS}

The units were filled with water for a period of one month until well establishment of wetland plant species. The pretreated campus domestic wastewater was applied after one month. The systems were operated under four different 
hydraulic conditions by varying hydraulic residence time as 2 , 4, 6 and 8 days (Table 4).

Table -4: Results of Pilot Scale Units

\begin{tabular}{|l|l|l|l|}
\hline Parameter & \multirow{2}{*}{ Inlet } & \multicolumn{3}{|l|}{ Outlet at HRT 2 Days } \\
\cline { 3 - 4 } & & PAGS & TLGS \\
\hline COD & 174 & 105 & 119 \\
\hline BOD & 48 & 34 & 36 \\
\hline TN & 0.30 & 0.23 & 0.22 \\
\hline TP & 2.25 & 1.68 & 1.35 \\
\hline Parameter & \multirow{2}{*}{ Inlet } & \multicolumn{2}{|l|}{ Outlet at HRT 4 Days } \\
\cline { 3 - 4 } & & PAGS & TLGS \\
\hline COD & 176 & 98 & 110 \\
\hline BOD & 42 & 33 & 29 \\
\hline TN & 0.28 & 0.26 & 0.23 \\
\hline TP & 2.22 & 1.59 & 1.11 \\
\hline Parameter & Inlet & Outlet at HRT 6 Days \\
\cline { 3 - 4 } & & PAGS & TLGS \\
\hline COD & 179 & 64 & 47 \\
\hline BOD & 39 & 22 & 21 \\
\hline TN & 0.32 & 0.22 & 0.21 \\
\hline TP & 2.27 & 1.38 & 1.18 \\
\hline Parameter & Inlet & Outlet at HRT 8 Days \\
\cline { 3 - 4 } & & PAGS & TLGS \\
\hline COD & 161 & 49 & 51 \\
\hline BOD & 36 & 16 & 17 \\
\hline TN & 0.22 & 0.12 & 0.14 \\
\hline TP & 2.19 & 0.55 & 0.41 \\
\hline
\end{tabular}

The COD removal efficiencies were $39,44,64$, and $69 \%$ for HRT of $2,4,6,8$ days, respectively. The BOD removal efficiencies were $29,21,43$, and $56 \%$ for HRT of $2,4,6,8$ days, respectively.

The TN removal efficiencies were $23,7,31$, and $45 \%$ for HRT of $2,4,6,8$ days, respectively. The TP removal efficiencies were $25,28,39$, and $75 \%$ for HRT of $2,4,6,8$ days, respectively (Chart 1$)$. There was a slight difference $(5 \%)$ in removal between HRT of 2 days and 4 days.

As the HRT increased to 6 days, there was $19 \%$ increase in COD removal when compared to COD removal at 4 days. The COD removal was doubled when there was an increase in HRT from 4 days to 8 days.

BOD removal dynamics slightly differs from COD removal dynamics. There was $8 \%$ decrease in efficiency when HRT increased from 2 days to 4 days. The removal efficiency doubled at 6 days HRT and it further increased to $56 \%$ at 8 days HRT.

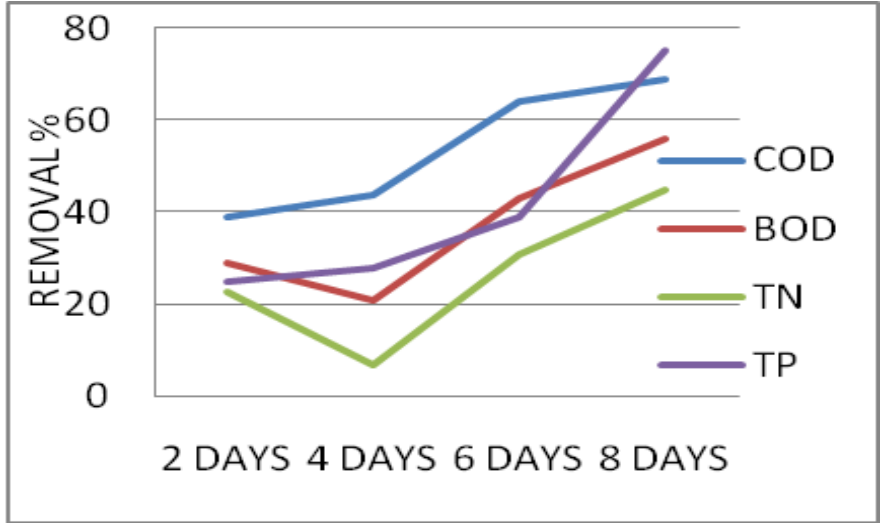

Chart -1: Organic and nutrient removal in PAGS

There was $2 / 3$ decrease in TN removal efficiency when HRT increased from 2 days to 4 days and 1/3 increase at 6 days HRT. The TN removal efficiency further increased to $45 \%$ at 8 days HRT. There was only 3\% increase in TP removal efficiency when there was an increase in HRT from 2 days to 4 days. And there was $11 \%$ increase at 6 days HRT compared to 4 days HRT. But the TP removal efficiency reached $75 \%$ at 8 days HRT. Similar study to determine the effectiveness of constructed wetlands to treat tertiary effluent wastewater generated from Paşaköy Advanced Biological Wastewater Treatment Plant showed that TP removal efficiency $(60 \%)$ might be due to use of gravel substrate. TP removal rates increased when the HRT was prolonged [15]. But, increasing HRT from 2 days to 4 days did not improve the efficiency in terms of $\mathrm{N}$ and $\mathrm{P}$ removal.

\subsection{Organics and Nutrient Removal in TLGS}

The COD removal efficiencies were $31,37,73$, and $68 \%$ for HRT of $2,4,6,8$ days, respectively. The BOD removal efficiencies were $25,30,46$, and $52 \%$ for HRT of $2,4,6,8$ days, respectively. The TN removal efficiencies were 26,17 , 34 , and $36 \%$ for HRT of 2, 4, 6, 8 days, respectively. The TP removal efficiencies were $40,50,48$, and $77 \%$ for HRT of 2 , 4, 6, 8 days, respectively (Chart 2).

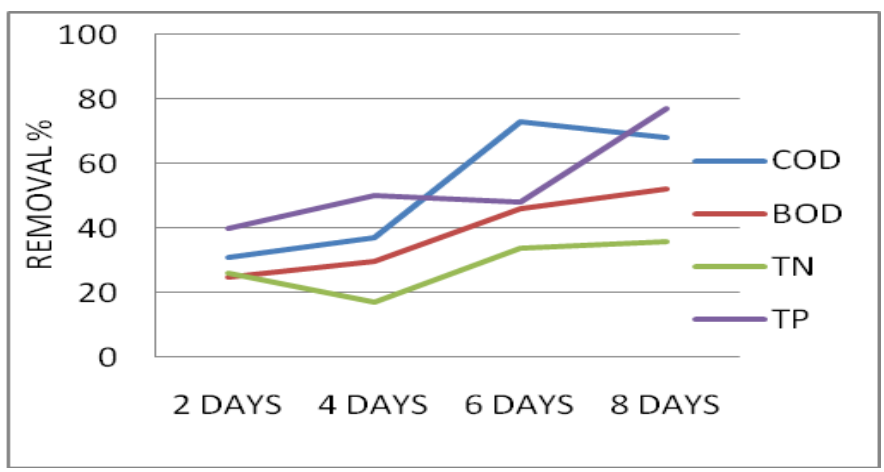

Chart -2: Organic and nutrient removal in TLGS 
There was an increasing trend in COD removal efficiency as the HRT increased from 2 days to 6 days. Further increase in HRT to 8 days did not change the COD removal efficiency. There was an increasing trend in BOD removal efficiency as the HRT increased from 2 days to 8 days as it doubled from $25 \%$ to $52 \%$ even as the effluent BOD concentration followed the trend of influent BOD concentration. Solano et al presented results of treatment efficiency of a pilot-scale subsurface flow constructed wetland planted with Phragmites australis and Typha latifolia remove BOD, COD, and TSS [16]. The TN removal efficiency decreased at 4 days HRT but increased at 6 days. There was only slight increase $(2 \%)$ in removal efficiency when HRT increased from 6 days to 8 days. There was an increasing trend in TP removal efficiency as the HRT increased from 2 days to 8 days but there was a slight decrease (2\%) at 4 days HRT which may probably be attributed to decrease in influent TP concentration (Fig. 5.26). Phragmites australis and Typha latifolia were the only plants that were able to establish successfully in wastewater treatment as reported by Calheiros et al [17, 18]. The treatment performance as reported by Calheiros et al was higher than the present study as the former use two-stage HSFCW in series planted with Phragmites australis and Typha latifolia [19].

\section{CONCLUSIONS}

The influent wastewater is rich in orgnic matter and contains high COD and BOD. Nutrients are present in source wastewater with high variability. A 6-day hydraulic residence time is suggested for an acceptable level of treatment in the pilot units. The presence of vegetation enhanced treatment efficiency. At 6-day HRT, among emergent plants tested, the unit planted with Phragmites australis was better in removal of BOD. The wide rooting zone and vast biofilm surface area of Phragmites australis might have resulted in the higher BOD removal. Phragmites australis was better in removal of organics and Typha latifolia was efficient in removal of nutrients.

\section{ACKNOWLEDGEMENTS}

The authors wish to express thanks to SRM University for providing land for the constructed wetland. Their sincere thanks are also given to the Department of Civil Engineering, School of Bioengineering, Department of Chemistry, and Department of Chemical Engineering for providing facilities for this research. The authors would like to thank the Estate Officer for all the logistics support.

\section{REFERENCES}

[1] Day.J.W. et al., 2004. The use of wetlands in the Mississippi Delta for wastewater assimilation : a review", Journal of Ocean and Coastal Management, 47, 671-691.
[2] Antoniasdis.A., Takavakoglou.V., Zalidis.G., Poulios.I., 2007. Development and evaluation of an alternative method for municipal wastewater treatment using homogeneous photocatalysis and constructed wetlands. Catalysis Today, 124. 260-265.

[3] Srinivasan Nerrala, Ricard W. Nearer, Bruce J.Lesiker, Russel A.Persyn., 2000. Improvement of domestic wastewater by subsurface flow constructed wetlands. BioResource Technology 75. 19-25.

[4] Abbas Al-Omari, Mannar Fayyad, 2003. Treatment of domestic wastewater by subsurface flow constructed wetlands in Jordan. Desalination 155, 27-39.

[5] Ciria M.P., Solano M.L., Soriano P., 2005. Role of marchophye typha latifolia in a constructed wetland for wastewater treatment and assessment for its potential as a biomass fuel. BioSystems Engineering 92(4). 535544.

[6] Keffala C., Gharbi.A., 2005. Nutrient and bacterial removal in constructed wetlands treating domestic wastewater. Desalination 185. 383-389.

[7] Shuh-Ren Jing, Yin-Feng Lin, Der-Yun Lee, Tze-Wen Wang, 2001. Nutrient removal from polluted river water using constructed wetlands. BioResource Technology 76. 131-135.

[8] Ruan.X., Xue.Y., Wu.J. Ni.L., Sun.M., Zhan.X., 2006. Treatment of polluted river water using pilotscale constructed wetlands. Bulletin of Environmental Contamination and Technology 76, 90-97.

[9] Scholz M., Sadowski.A.J., Harrington.R., Carrol.P., 2007. Integrated constructed wetlands assessment and design for phosphate removal. Biosystems Engineering 97. 415-423.

[10] Variga Sawaittayolthin, Chongrak Polpvasert, 2007. Nitrogen mass balance and microbial analysis of constructed wetlands treating municipal landfill leachate. Bio Resource Technology 98, 565-570.

[11] Chi-Yuan Lee, Chun-Chih Lee, Fang-Yin Lee, SzuKing Tseng, Chiu-Tung Lia, 2004. Performance of subsurface flow constructed wetland taking pretreated swine effluent under heavy loads. BioResource Technology 92. 173-179.

[12] Paolo Mantori, Marta Marmiroli, Elena Maestri, Simona Tagliavimi, Sergio Piccinini, Nelson Marmiroli, 2005. Application of a horizontal subsurface flow constructed wetland on treatment of dairy parlor wastewater. BioResource Technology 88, 85-94.

[13] Alenka Ojstrsek, Darinka Fakin, Danijel Vrhovsek, 2007. Residual dyebath purification using a system of constructed wetland. Dyes and Pigments 74. 503-507.

[14] APHA, 1995, "Standard Methods for the Examination of Water and Wastewater", A.E. Greenberg, "edr.", $19^{\text {th }}$ edition, American Public Health Association (APHA), American Water Works Association (AWWA), and the Water Environmental Federation (WEF): Washington DC. 
[15] Tang, X.Q., Huang, S.L., and Scholz, M., 2009, "Comparison of phosphorus removal between vertical subsurface flow constructed wetlands with different substrates", Water and Environment Journal, 23 (3), pp. 180-188.

[16] Solano, M. L., Soriano, P., and Ciria, M.P., 2004, "Constructed Wetlands as a Sustainable Solution for Wastewater Treatment in Small Villages", Biosystems Engineering, 87(1), pp. 109-118.

[17] Calheiros, S.C., Rangel, A., and Castro, P., 2007, "Constructed Wetland Systems Vegetated with Different Plants for the Treatment of Tannery Wastewater", Water Research, 41, pp. 1790-1798.

[18] Calheiros, C.S.C., Rangel, A., and Castro, P.M., 2008, "Evaluation of Different Substrates to Support the Growth of Typha latifolia in Constructed Wetlands Treating Tannery Wastewater over Long-term Operation”, Bio Resources Technology, 99, pp. 68666877.

[19] Sheoran, A.S., 2006, “A laboratory treatment study of acid mine water of wetlands with emergent macrophyte (Typha augustata)", International Journal of Mining, Reclamation and Environment, 20(3), pp. 209-222.

\section{BIOGRAPHIES}

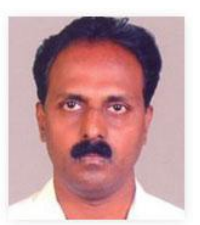

Dr.G.Baskar has been working as Professor in the Department of Civil Engineering, SRM University. His interest is in Constructed Wetland.

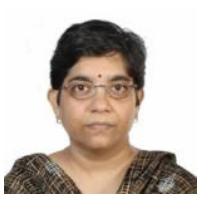

Dr.V.T. Deeptha has been working as Assistant professor in the Department of Civil Engineering, SRM University. Her interest is in coastal physical processes, wetland and mangroves.

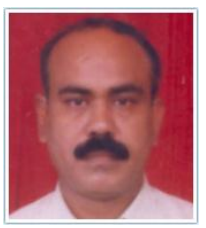

Dr. R. Annadurai is Head of Department, Department of Civil Engineering, SRM University. He has authored one book. 